\title{
First report of parasitism by Hexametra boddaertii (Nematoda: Ascaridae) in Oxyrhopus guibei (Serpentes: Colubridae)
}

\author{
María E. Peichoto ${ }^{a, *}$, Matías N. Sánchez ${ }^{\mathrm{a}}$, Ariel López ${ }^{\mathrm{b}}$, Martín Salas ${ }^{\mathrm{b}}$, María R. Rivero ${ }^{\mathrm{a}}$, \\ Pamela Teibler ${ }^{\mathrm{c}}$, Gislayne de Melo Toledo ${ }^{\mathrm{d}}$, Flávio L. Tavares ${ }^{\mathrm{e}}$ \\ a Consejo Nacional de Investigaciones Científicas y Técnicas (CONICET), Ministerio de Ciencia Tecnología e Innovación Productiva; Instituto Nacional de \\ Medicina Tropical (INMeT), Ministerio de Salud de la Nación, Neuquén y Jujuy s/n, 3370 Puerto Iguazú, Argentina \\ b Instituto Nacional de Medicina Tropical (INMeT), Ministerio de Salud de la Nación, Neuquén y Jujuy s/n, 3370 Puerto Iguazú, Argentina \\ ${ }^{c}$ Universidad Nacional del Nordeste (UNNE), Facultad de Ciencias Veterinarias (FCV), Sargento Cabral 2139, 3400, Corrientes, Argentina \\ d Universidade Estadual Paulista (UNESP), Campus de Botucatu, Instituto de Biociências, Departamento de Parasitologia, Botucatu, São Paulo, Brazil \\ e Universidade Federal da Integração Latino-Americana (UNILA), Av. Silvio Américo Sasdelli, 1842 - Vila A, Foz do Iguaçu, PR, CEP 85866-000, Brazil
}

\section{A R T I C L E I N F O}

\section{Article history:}

Received 1 November 2015

Received in revised form 3 May 2016

Accepted 13 May 2016

\section{Keywords:}

Reptilia

Colubrid snake

Oxyrhopus guibei

Helminthiasis

Hexametra boddaertii

\begin{abstract}
A B S T R A C T
The current study summarizes the postmortem examination of a specimen of Oxyrhopus guibei (Serpentes, Colubridae) collected in Iguazu National Park (Argentina), and found deceased a week following arrival to the serpentarium of the National Institute of Tropical Medicine (Argentina). Although the snake appeared to be in good health, a necropsy performed following its death identified the presence of a large number of roundworms in the coelomic cavity, with indications of peritonitis and serosal adherence. Additional observations from the necropsy revealed small calcifications in the mesothelium of the coelomic cavity; solid and expressive content in the gallbladder; massive gastrointestinal obstruction due to nematodes; and lung edema and congestion. Histopathological analyses of lung sections also showed proliferative heterophilic and histiocytic pneumonia. Parasites isolated from both the intestine and coelomic cavity were identified as Hexametra boddaertii by a combination of light and scanning electron microscopic examination. Results from this necropsy identify $O$. guibei as a new host for $\mathrm{H}$. boddaertii, and is the first report of a natural infection by Hexametra in Argentina. Since Hexametra parasites may contribute to several pathological conditions in humans, and with the recent availability of $O$. guibei specimens through the illegal pet trade, it is necessary to consider the possibility of zoonotic helminth transmission of Hexametra from snake to human.
\end{abstract}

(c) 2016 Elsevier B.V. All rights reserved.
Despite the diversity of parasites observed in reptiles, studies examining the helminth fauna of snakes native to the Neotropic ecozone have been relatively scarce (Mati et al., 2015). In particular, there are only a few examples of parasitism affecting snakes in Argentina (Boero and Led, 1971; Lamas and Lunaschi, 2009; Mati et al., 2015; Poumarau, 1968), and there is a limited understanding of endoparasites in wild caught snakes (Mati et al., 2015).

Among serpents from the Neotropics, Guibe's false coral snake, Oxyrhopus guibei (Hoge and Romano, 1976), inhabits regions of southeastern Brazil, and west into Bolivia, and Paraguay, and throughout the northernmost provinces of Argentina (Uetz et al., 2015). Like many other terrestrial colubrid snakes, this generalist predator feeds on lizards and rodents, and exhibits a primarily cre-

\footnotetext{
* Corresponding author.

E-mail addresses: mepeichoto@yahoo.com.ar, mepeichoto@conicet.gov.ar (M.E. Peichoto).
}

puscular to nocturnal activity pattern (Alencar et al., 2009; Sazima and Abe, 1991). O. guibei displays a colorful banding pattern that mimics the highly venomous Coral Snake Micrurus frontalis (Elapidae) (Giraudo, 2001), and therefore is often referred to as the False Coral Snake. It is also worth mentioning that, like so many other colorful snakes, $O$. guibei is a part of the illegal pet trade (Souza et al., 2007).

The current study summarizes the results of a postmortem examination of an adult female $O$. guibei specimen captured in Iguazu National Park (Misiones, Argentina). The snake was captured on April 28th, 2015, in accordance with authorization from the National Park Administration (APN) $\mathrm{N}^{\circ} 335 / 13$, transported to the serpentarium of the National Institute of Tropical Medicine (INMeT) (Argentina), and found unexpectedly dead one week later.

Upon arrival to INMeT, the snake weighed $370 \mathrm{~g}$ with a snoutvent length of $92.5 \mathrm{~cm}$ and total length of $101 \mathrm{~cm}$. It entered into a quarantine area where regular veterinary examinations and 

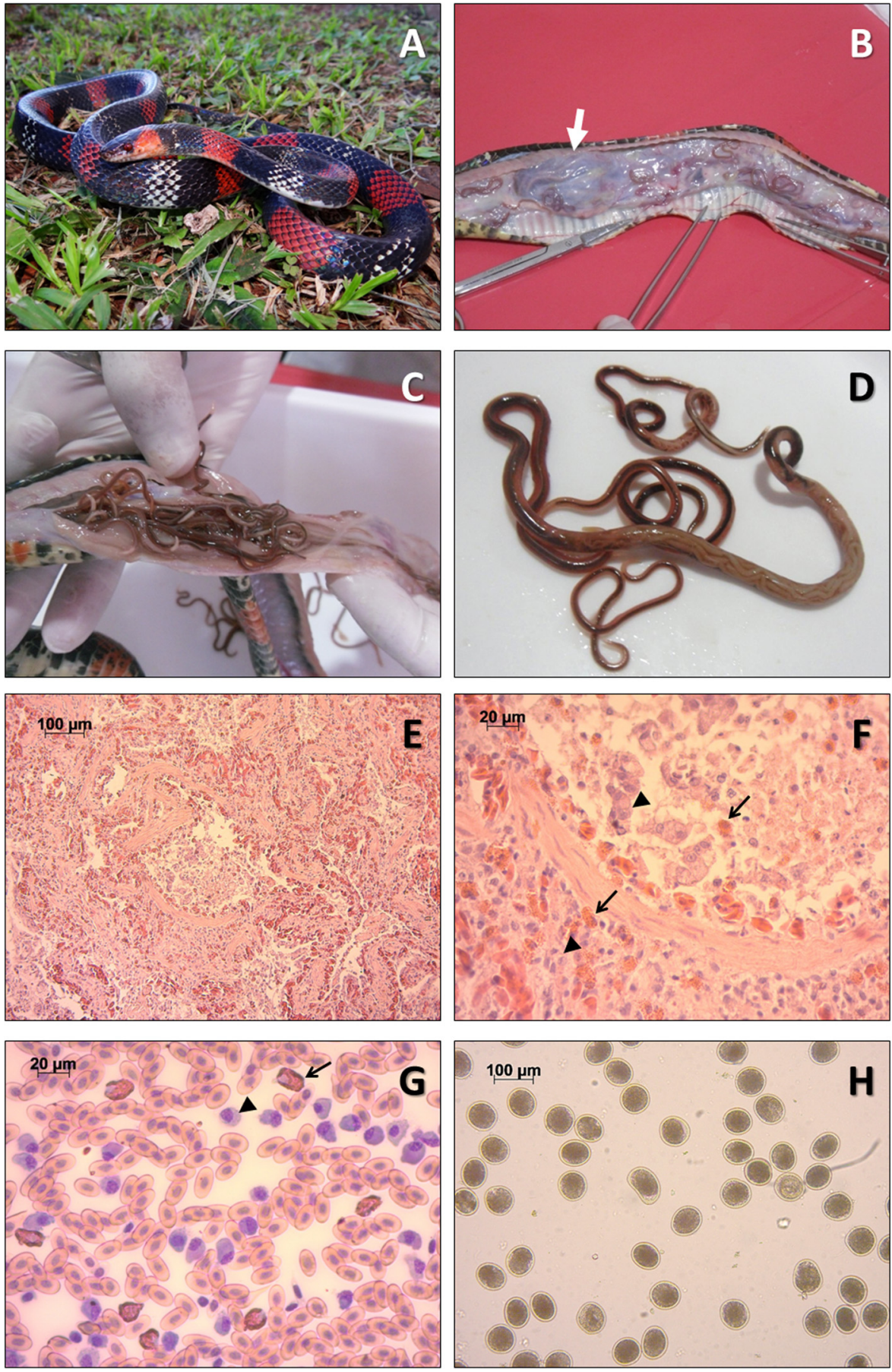

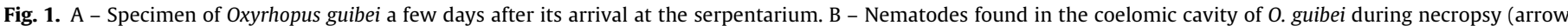

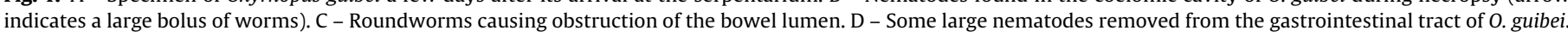

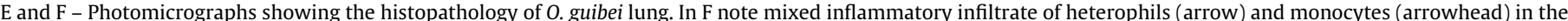

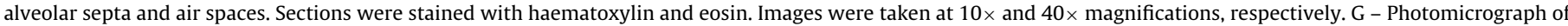

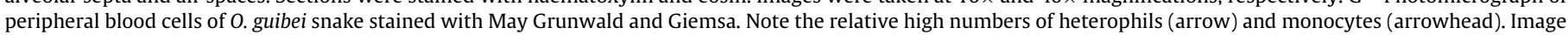
was taken at $40 \times$ magnification. $\mathrm{H}$ - Photomicrograph of Ascarididae-type eggs in feces of 0 . guibei. Note their abundant presence in a microscopic field of $\times 10$.

screens were systematically performed. Although the specimen was in captivity for only a short period of time, activity levels appeared normal, and there were no signs of behavioral abnormalities, or detectable disease-related symptoms. Nevertheless, it is worth mentioning that during initial observations, the snake appeared to have an enlarged mass near the middle region of its body, which at the time was assumed to be a distension in the stomach caused by consumption of a natural prey item. Although the specimen appeared to be in good health (Fig. 1A), it was unex- pectedly found dead with its mouth agape a week after its arrival to the INMeT serpentarium. Visual observation of the deceased snake identified fluid draining from the mouth and there were no detectable signs of bleeding. Additional external evaluation suggested that the snake was in a good nutritional state, however, immediately following the start of the necropsy a significant abundance of roundworms were seen in the body cavity. A total of 68 nematodes were collected and found throughout the whole extension of the coelomic cavity (Fig. 1B), ranging from the upper 

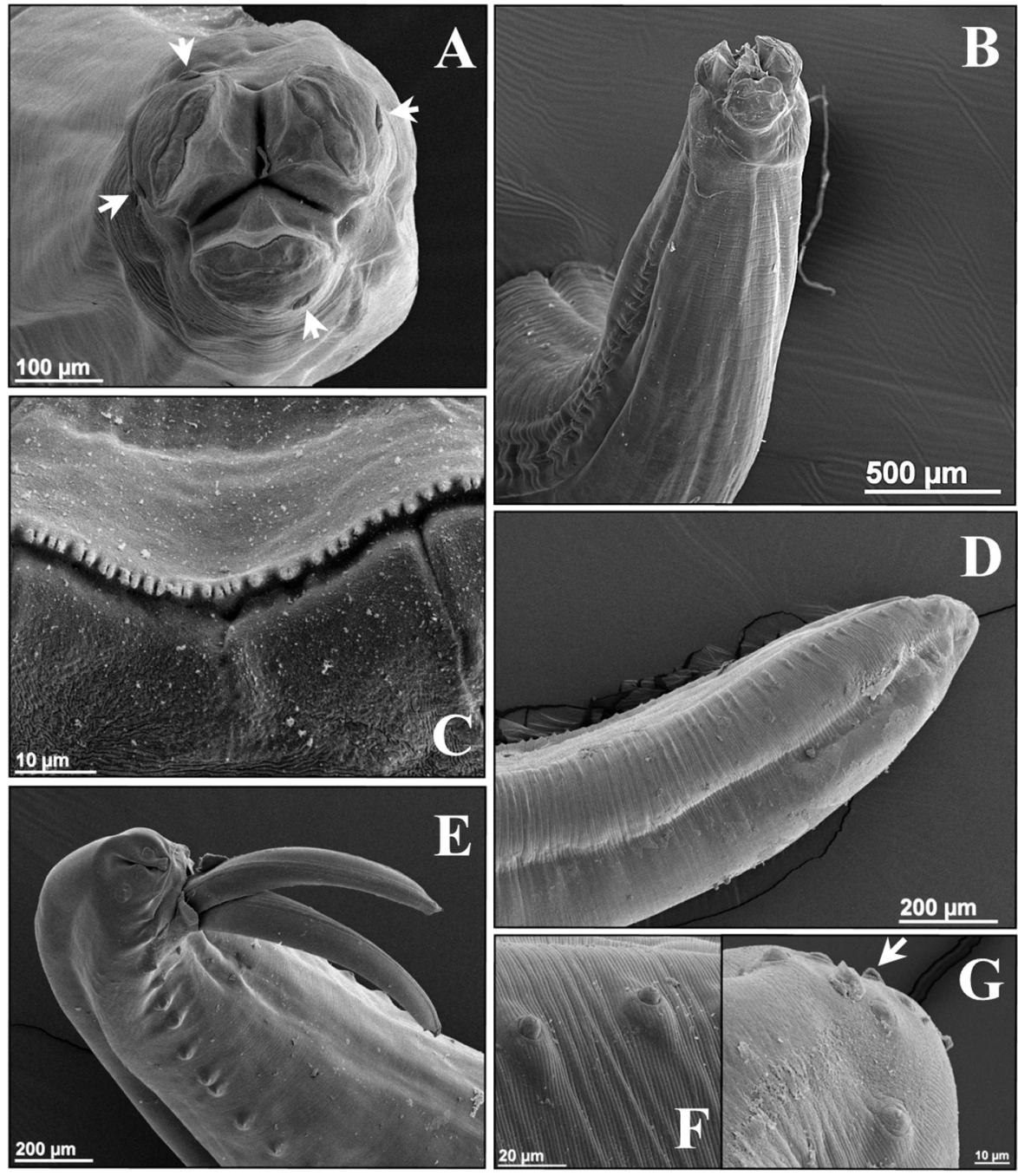

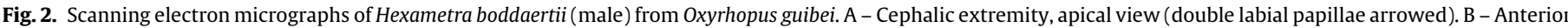

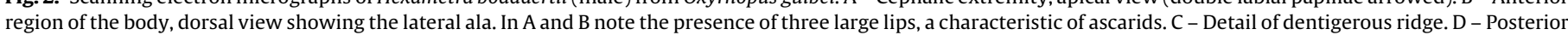

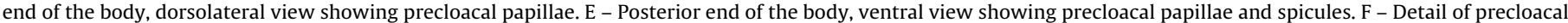
papillae. G - Tail, dorsolateral view (postcloacal papillae, terminal mucron arrowed).

gastrointestinal tract to the pericloacal region. Larger nematodes contributed to a significant gastrointestinal obstruction (Fig. 1C and D), with a total of 52 individual nematodes collected from the whole digestive tract. Other significant findings of the necropsy were: peritonitis with serosal adherence; small calcifications in the mesothelium of the coelomic cavity; solid and expressive content in the gallbladder (which is strongly suggestive of obstruction); and lung edema and congestion.

Histopathological analyses of lung sections $(5 \mu \mathrm{m})$ revealed proliferative heterophilic and histiocytic pneumonia, with images showing heterophils and monocytes broadening the alveolar septa and filling the faveolae. In addition, necrotic cellular debris resulting from the destruction of the basement membrane (Fig. 1E and F) was also observed. These findings are in accordance with the inflammatory patterns observed on the microscopic examination of smears from the oral exudate. Regarding the gastric and intestinal tissue sections, the mucosa was congested and inflamed, and rounded structures compatible with parasitic forms were surrounded by fibrotic and/or inflammatory tissue in the submucosa (data not shown).

During the necropsy, peripheral blood was collected by aortic puncture, however, due to limited resources, white blood cell (WBC) counts were not performed. Nevertheless, based on a subjec- tive blood smear evaluation, the concentration of WBCs appeared to be significantly elevated and consisted predominantly of heterophils and monocytes (Fig. 1G), which is indicative of infection and/or stress leukocytosis. Biochemical analyses of serum was conducted using VetScan ${ }^{\circledR}$ Avian/Reptilian Profile Plus (Abaxis, Inc.), and revealed high levels $(>200 \mu \mathrm{mol} / \mathrm{L}$ ) of bile acids, which is in accordance with the gallbladder obstruction verified during the necropsy. All other biochemical parameters examined were within the normal ranges for captive colubrid snakes (Coz-Rakovac et al., 2011): aspartate aminotransferase $461 \mathrm{U} / \mathrm{L}$, creatine kinase $935 \mathrm{U} / \mathrm{L}$, uric acid $5.7 \mathrm{mg} / \mathrm{dL}$, glucose $13 \mathrm{mg} / \mathrm{dL}$, total calcium $10 \mathrm{mg} / \mathrm{dL}$, phosphorus $8.3 \mathrm{mg} / \mathrm{dL}$, total protein $6.1 \mathrm{~g} / \mathrm{dL}$, albumin $1.1 \mathrm{~g} / \mathrm{dL}$, globulin $5.0 \mathrm{~g} / \mathrm{dL}$, potassium $4.5 \mathrm{mmol} / \mathrm{L}$, sodium $148 \mathrm{mmol} / \mathrm{L}$.

A parasitological analysis of a fecal sample collected three days prior to the snake's death revealed abundant Ascarididae-type eggs (Fig. $1 \mathrm{H}$ ) by both sedimentation and flotation concentration techniques. Unfortunately, all veterinary efforts attempting to de-worm the snake - therapy with $10 \%$ fenbendazole suspension (Panacur, Intervet) orally at a single dose of $25 \mathrm{mg} / \mathrm{kg}$ body weight, and cleaning and disinfection of its cage frequently - were unsuccessful to keep the individual alive. It was even not possible to collect a fecal sample after treatment. It should be noted that serpent fatalities due to severe ascaridid infections have been previously reported 
(Rataj et al., 2011). Following the necropsy, some nematodes collected from both the gastrointestinal tract and the coelomic cavity were cleared with lactic acid and prepared for microscopic examination, while other nematodes were gold coated and examined by scanning electron microscopy (SEM) using a JEOL 5800 LV SEM at an accelerating voltage of $15 \mathrm{Kv}$ (SEM Service from the University of Northeastern Argentina). Both intestinal and coelomic parasites were identified as Hexametra boddaertii (Fig. 2A-F) based on size and morphological characteristics as described by Vicente et al. (1993) and Sprent (1978). Body length of H. boddaertii isolated from the gastrointestinal tract ranged from 52 to $159 \mathrm{~mm}$ ( mean $=81.45 \pm 22.93 \mathrm{~mm}, \mathrm{n}=30$ ), whereas those collected from the coelomic cavity exhibited a smaller body length and ranged from 18 to $72 \mathrm{~mm}$ ( mean $=42.32 \pm 11.03 \mathrm{~mm}, \mathrm{n}=30$ ). The body measurements determined in the current study are in agreement with those reported by Sprent (1978). H. boddaertii egg sizes ranged from 72.39 to $90.82 \mu \mathrm{m}$ ( mean $=80.54 \pm 4.36 \mu \mathrm{m}, \mathrm{n}=60$ ) in length, and $59.48-79.40 \mu \mathrm{m}$ ( mean $=71.25 \pm 5.04 \mu \mathrm{m}, \mathrm{n}=60$ ) in width. These measurements are in accordance with those reported by Sprent (1978) and Bursey et al. (1995).

$H$. boddaertii was originally isolated and described by Baird (1860), who removed a single female specimen from a Boddaert's tropical racer (Mastigodryas boddaerti), a colubrid snake found throughout much of South America. Since then, several neotropical colubrid snakes have been identified as host for this parasite including: Oxyrhopus trigeminus and Philodryas patagoniensis from Brazil (Sprent, 1978), Spilotes pullatus and Trimorphodon biscutatus from Costa Rica (Bursey and Brooks, 2011), and a Philodryas baroni specimen from an unknown locality (Hartdegen and Gamble, 2002). The current study reports the presence of $H$. boddaertii in an individual $O$. guibei captured in Argentina, which not only identifies a new host for this parasite, but also reports the first country record for $\mathrm{H}$. boddaertii. It is important to note that some nematodes removed from the gastrointestinal tract exhibited a body length greater than $10 \mathrm{~cm}$, suggesting that most, if not all of the nematodes found during the necropsy were in the adult phase of their life cycle. This strongly indicates that the severe parasitism seen in this individual snake was established well before its capture and arrival to the INMeT serpentarium, and that the transmission of $H$. boddaertii likely occurred through the consumption of infected frogs/rodents/lizards in the forest (see Anderson (2000) for review of the life cycle of $H$. boddaertii). Likewise, Vrcibradic et al. (2000, 1999) reported the presence of immature ascarids which were identified as $H$. boddaerti from the coelomic cavity of several Brazilian lizards. Thus, this report certainly contributes to the current knowledge of the parasitic fauna of wild squamates from Argentina.

Human handling of snakes infected with $H$. boddaertii may permit transmission of the parasite and pose a risk to human health. In fact, the transmission of Hexametra larvae from fecal excretion of the snake Bitis arietans to the primate Macaca fascicularis has been documented (Petter et al., 1967), and further suggest that, if encountered, Hexametra could be transmitted to humans. It has also been suggested that Hexametra may be the causative nematode contributing to the ocular disease known as diffuse unilateral subacute neuroretinitis (DUSN) in Brazil (Souza et al., 2005). Hexametra has also been shown to exhibit life cycle characteristics similar to those of Toxocara canis, one of the major causative parasites that contributes to visceral larva migrans (VLM) in humans (Bowman, 1987). Therefore, it may be safe to assume that Hexametra parasites may contribute to VLM and other potentially harmful pathological conditions (Bowman, 1987). The recent popularity of O. guibei in the pet trade, although being illegally sold (Souza et al., 2007), may cause possible zoonotic helminth transmission of Hexametra from snake to human, and special care must be taken while manipulating this snake.
The snake reported here was deposited in the Herpetological Collection of the National Institute of Tropical Medicine, Puerto Iguazú, Argentina (code INMeT 017). Representative male and female specimens of $H$. boddaertii have been maintained separately in different preservative solutions and deposited in the Helminthological Collection of the National Institute of Tropical Medicine, Puerto Iguazú, Argentina (code INMeT ES_001:15).

\section{Acknowledgements}

We would like to thank the National Parks Administration (APN, Argentina) for permission to conduct research at the Iguazu National Park, and park rangers Marcio Antunez and Nahuel Valente for their support during field work. We thank biologists Cecilia Galíndez and Cristina Salgado for helping with the SEM sample preparation, and veterinarians Mathias Dislich and Laiz Padilha for helping with the biochemical analysis. We appreciate help from Dr. Anthony Saviola with the English revision of the manuscript. We acknowledge financial support by INMeT, CONICET (PIP 112201301-00126-CO), and Agencia Nacional de Promoción Científica y Tecnológica (PICT-2013-1238) from Argentina.

\section{References}

Alencar, L.R.V., Galdino, C.A.B., Nascimento, L.B., 2009. Oxyrhopus guibei (False coral snake): diet. Herpetol. Rev. 40, 357-358.

Anderson, R.C., 2000. Nematode Parasites of Vertebrates: Their Development and Transmission, 2nd ed. CABI Publishing, Wallingford, pp. 650.

Boero, J.J., Led, J.E., 1971. El parasitismo de la fauna autóctona: (V) los parásitos de las aves argentinas (VI) los parásitos de los ofidios argentinos (VII) los parásitos de los murciélagos argentinos. Analecta Vet. 3, 91-103.

Bowman, D.D., 1987. Diagnostic morphology of four larval ascaridoid nematodes that may cause visceral larva migrans: Toxascaris leonina, Baylisascaris procyonis, Lagochilascaris sprenti, and Hexametra leidyi. J. Parasitol. 73, $1198-1215$.

Bursey, C.R., Brooks, D.R., 2011. Nematode parasites of costa rican snakes (Serpentes) with description of a new species of Abbreviata (Physalopteridae). Comp. Parasitol. 78, 333-358.

Bursey, C.R., Goldberg, S.R., Secor, S.M., 1995. Hexametra boddaertii (Nematoda: Ascarididae) in the sidewinder, Crotalus cerastes (Crotalidae), from California. J. Helminthol. Soc. Wash. 62, 78-80.

Coz-Rakovac, R., Lisicic, D., Smuc, T., Popovic, N.T., Strunjak-Perovic, I., Jadan, M., Tadic, Z., Dujakovic, J.J., 2011. Classification modeling of physiological stages in captive balkan whip snakes using blood biochemistry parameters. J. Herpetol $45,525-529$.

Giraudo, A.R., 2001. Serpientes de la Selva Paranaense y del Chaco Húmedo. L.O.L.A, Buenos Aires, pp. 328

Hartdegen, R.W., Gamble, K.C., 2002. Philodryas baroni (Baron's racer) endoparasitism. Herpetol. Rev. 33, 141

Hoge, A.R., Romano, S.A.R.W.L., 1976. Description of a new subspecies of Oxyrhopus Wagler (Serpentes: Colubridae). Mem. Inst. Butantan 41/42, 55-62.

Lamas, M.F., Lunaschi, L.I., 2009. Primer registro de Centrorhynchus sp. (Acanthocephala: Centrorhynchidae) en Leptophis ahaetulla marginatus (Colubridae) de Argentina. Cuad. Herpetol. 23, 45-49.

Mati, V.L.T., Pinto, H.A., Melo, A.L., 2015. Helminths of Liophis miliaris (Squamata, Dipsadidae): a list of species and new records. Helminthologia 52, 159-166.

Petter, A.J., Bain, O., Orcel, L., 1967. Larva migrans: an experimental infection in a primate produced by an ascarid from a snake. Ann. Parasit. Hum. Comp. 2, 207-210.

Poumarau, E.M.C., 1968. Trematodes de ofidios de la Argentina rev: mus. Rev. Mus. Argent. Cienc. Nat. "Bernardino Rivadavia” Inst. Nac. Investig. Cienc. Nat., Parasitol. 1, 1-129.

Rataj, A.V., Lindtner-Knific, R., Vlahovic, K., Mavri, U., Dovc, A., 2011. Parasites in pet reptiles. Acta Vet. Scand. 53, 33.

Sazima, I., Abe, A.S., 1991. Habits of five Brazilian snakes with coral-snake pattern, including a summary of defensive tactics. Stud. Neotrop. Fauna Environ. 26, $159-164$.

Souza, E.C., Casella, A.M., Nakashima, Y., Monteiro, M.L., 2005. Clinical features and outcomes of patients with diffuse unilateral subacute neuroretinitis treated with oral albendazole. Am. J. Ophthalmol. 140, 437-445.

Souza, V.L., Santos T.M. d. Peña, A.P., Luz, V.L.F., Reis, I.J.D., 2007. Caracterização dos répteis descartados por mantenedores particulares e entregues ao Centro de Conservação e Manejo de Répteis e Anfíbios - RAN. Rev. Biol. Neotrop. 4, 149-160.

Sprent, J.F.A., 1978. Ascaridoid nematodes of amphibians and reptiles: Polydelphis, Travassosascaris n.g. and Hexametra. J. Helminthol. 52, 355-384.

Uetz, P., Hallermann, J., Hosek, J., 2015. The Reptile Database. In http://reptiledatabase.reptarium.cz/species?genus=0xyrhopus\&species=guibei. 
Vicente, J.J., Rodrigues H. d.O. Gomes, D.C., Pinto, R.M., 1993. Nematoides do Brasil: parte III: nematoides de Répteis. Rev. Bras. Zool. 10, 19-168.

Vrcibradic, D., Rocha, C.F.D., Ribas, S.C., Vicente, J.J., 1999. Nematodes infecting the skink Mabuya frenata in Valinhos, São Paulo State, southeastern Brazil. Amphibia-Reptilia 20, 333-339.
Vrcibradic, D., Cunha-Barros, M., Vicente, J.J., Galdino, C.A.C., Hatano, F.H., Sluys, M.V., Rocha, C.F.D., 2000. Nematode infection patterns in four sympatric

lizards from a restinga habitat (Jurubatiba) in Rio de Janeiro state, southeastern Brazil. Amphibia-Reptilia 21, 307-316. 